\title{
Revolutionary Tourism. New Opportunity For Armenia
}

\section{Gayane Tovmasyan}

$\mathrm{PhD}$ in Economics, Senior Researcher at "AMBERD" Research Center of the Armenian State University of Economics, Professor at the Public Administration Academy of the Republic of Armenia, the Republic of Armenia

\begin{abstract}
This paper summarizes the arguments and counterarguments within the scientific discussion on the issues of revolutions and its possible effects on tourism. Revolutionary tourism describes the visits to revolutionary places. It may be interesting for politicians, researchers, state workers, journalists, writers, also amateurs of adventures and just tourists.

The main purpose of the research is to analyze the meaning of the revolutionary tourism, its roots and main history, aims and directions and to find out the opportunities to develop that type of tourism in Armenia.

The investigation of the topic showed, that revolutionary tourism is well developed in China and Russia, besides, in many places, such as Palestine, Egypt, Israel, Tunisia, despite the revolutions, wars and dangers, tourists are curious to visit that places.
\end{abstract}

The methodological tools for the research were the following methods: analysis and synthesis, micro and macro analysis, historical analysis. The object of the research is Armenia, where a velvet revolution took place in April-May 2018. The revolution was peaceful, without blood, and was interesting for international media as well. Based on Armenian experience, some countries started the same protests in their countries (for example Russian, France).

The empirical analysis shows that in the days of revolution, many tourists came to Armenia, who were admired with the national spirit of Armenians. They were astonished to see how Armenians sing and dance in the streets, presenting it as a unique Armenian way of revolution.

The research empirically confirms and theoretically proves that Armenia has a great potential for tourism development and this case should also be used as a positive factor to present Armenia as a safe country abroad, and to develop a new type of tourism - revolutionary or "velvet" tourism in the country.

The main conclusion is that tourism marketing in Armenia should include also the fact of velvet revolution which will be interesting for many tourists, especially Chinese and Russian red tourists.

The results of the research can be useful for the state organs, private sector to accomplish marketing activities, also for researchers of tourism sphere.

Keywords: tourism, revolution, red tourism, protest, velvet, Armenia.

JEL Classification: Z3, L83, D74.

(C) The Author, 2018. This article is published with open access at Sumy State University.

\section{Introduction}

Tourism is developing rapidly worldwide. The number of international tourists reached up to 1.322 million in the world in 2017 (International Tourism Results 2017). The total contribution of Travel \& Tourism to world GDP in 2017 was USD 8,272.3bn (10.4\% of GDP) in 2017. The direct contribution of Travel \& Tourism to GDP was USD 2,570.1bn (3.2\% of total GDP) in 2017. In 2017 Travel \& Tourism directly supported $118,454,000$ jobs $(3.8 \%$ of total employment), and the total contribution to employment was $9.9 \%$ of total employment (313,221,000 jobs). Visitor exports generated USD 1,494.2bn (6.5\% of total exports) in 2017. Travel \& Tourism investment in 2017 was USD882.4bn, or 4.5\% of total investment (Travel and Tourism economic Impact, World, 2018).

Revolutionary tourism may be described as a type of tourism when tourists visit countries or cities where has been or is taking place a revolution in order to participate or just to see it.

Nowadays there is a term of "red tourism" which is a type of tourism in China and Russia. In this case, tourists visit historical sites connected with the history of the Communist Party, communist leaders and their revolutionary past. For example, in Russia these are places connected with Lenin's life, the October Revolution 
and the Communist Party (Vodopyanova A.). The main visits to China take place in historic sites connected with the life of Mao Zedong, other communist leaders and the country's revolutionary past. Chinese Red tourism routes have been developed by Chinese authorities for Chinese citizens, while Russian red tourism routes mostly attract Chinese tourists' attention (Wong E.).

\section{Literature review and presentation of the current state in the world}

Red tourism emerged as a phenomenon in 1949, when the Chinese began their pilgrimage to holy sites of the communist party, in order to live in a revolutionary spirit and to repeat the big step of the Chinese Comunists of 1934-1936 years (Hunse L.).

The concept of "red tourism" emerged in 2004, in China, when a national program was developed for domestic tourism development. The program included 30 routes and about 100 sites for visit. The project was aimed at raising the national spirit of the population and promoting the economic development of the poorer regions of the country. At present, Chinese red tourism objects are estimated to receive at around 700 million tourists every year (Vodopyanova A.).

The main locations in China which are places of red tourism are the following: Gutian (where Mao Zedong stamped out ultra-democracy), Yan'an (birthplace of the revolution), Jinggangshan, Zuyni, Shaoshan (birthplace of Zedong), Hainan Island, Nanjie, Shangai, Chongqing, Ruijin, Tingzhou, etc.

For the Russian consciousness "red" theme is, first of all, the images of the USSR and Lenin. That figure represents the leader of world proletariat movement of world communist forces, which originated in Russia. Development direction of "red" tourism is impossible without a visit to key cities in the history of the person of Vladimir Lenin - Kazan, Moscow, St. Petersburg and the capital of the "Red Route" - Ulyanovsk (Shanchzhun Z., 2009).

The flow of Chinese tourists to Russia was a motive for the development of red tourism in the country, which was connected with the signed intergovernmental agreement allowing group tourists to enter Russia without a visa (Order of 15 May 2006). The first Russian Red Route was introduced to Chinese tourists in 2013. In 2017 1.5 million Chinese tourists visited Russia (The number of tourists from China to Russia...). We should also note that Red tourism has been included in Russia's tourism development strategy till 2020 (Red tourism...).

Recently, in many countries have been revolutions. However, there are not any true estimations about the impact of the revolution on the increase or decrease of tourism sphere. Besides, the influence is connected with the revolution type: it was peaceful or not. However, the wars and revolutions put the countries in the world top news, and many people get to know about the country.

Here are some data from UNWTO, that surprises a lot. It shows the world's fastest growing tourism destinations in 2017. The first is Palestine, where according to UNWTO the occupied territories witnessed a 57.8 per cent rise in international arrivals in 2017. The second is Egypt. After the crash of Russian passenger plane in 2015, which was attributed to terrorism, UK and Russia refuse serving the holiday resort. However, the number of international arrivals increased in 51 per cent, welcoming 8 million tourists in 2017 (in 2010 the number was 14 million). Another country in the list is Tunisia, which had a revolution in 2010-2011, besides it suffered a similar fate to Egypt's following the Sousse beach massacre of 2015, when a gunman killed 38 people. UNWTO reported that arrivals are up by 32.5 per cent in 2017 (7.5 million in 2017). Another country is Nicaragua, which is emerging as a Central America's fastest growing destination with tourist arrivals up 28.4 per cent in 2017 ( 2 million). As well as palm-fringed beaches, the country's revolutionary history and verdant interior adds to the appeal. Israel showed 25.1 per cent growth in the number of tourists (3.7 million). Israel and Palestine are considered to be the fastest growing destinations in the Middle East (Haines, 2017).

So, the above mentioned shows, that despite the revolutions, wars and dangers, tourists are curious and visit to that places. Thus, taking into account the peaceful revolution in Armenia, we may say, that the main issue in our case will be good marketing presentation of the country abroad as a safe and secure country.

\section{Methods}

The purpose of the research is to analyze the opportunities of revolutionary tourism development in the Republic of Armenia.

The object of the research is revolutionary tourism in Armenia.

The subject of this research is the impact of revolution on tourism development in Armenia. 
The main methods used in the research are as follows: analysis and synthesis, micro and macro analysis, historical analysis.

In the research a variety of data are used from the National Statistical Service of RA, The World Travel \& Tourism Council (WTTC) and other national and international organizations, state organs, medias, etc.

\section{Discussion}

In Armenia tourism was announced as a main sector of economy. In Armenia, the state administration body of tourism sphere is the State Tourism Commitee of the Ministry of Economic Development and Investments, which is responsible for the development and implementation of the state policy in the sphere.

In Armenia the direct contribution of Travel \& Tourism to GDP in Armenia in 2017 was AMD 231.7 bn (USD $477.7 \mathrm{mn}$ ), $4.4 \%$ of total GDP in 2017.

The total contribution of Travel \& Tourism to GDP was AMD 834.1bn (USD1,719.7 mn), 15.7\% of GDP in 2017 in Armenia.

In 2017 Travel \& Tourism directly supported 44,500 jobs (3.9\% of total employment).

In 2017, the total contribution of Travel \& Tourism to employment, including jobs indirectly supported by the industry was $14.1 \%$ of total employment (162,000 jobs).

Visitor exports generated AMD 529.8 bn (USD 1,092.4 mn), 29.2\% of total exports in 2017.

Travel \& Tourism investment in 2017 was AMD52.8 bn, $4.6 \%$ of total investment (USD108.9 mn) (Travel \& Tourism Economic Impact 2018 Armenia).

In 2017 1,494,779 tourists visited Armenia (Social-Economic Situation of the RA, 2017), which is 18.7\% more than last year. The number of tourists from Russia in 2017 was 303440, and the number of tourists from China was 5021 .

According to the data of National statistical service of the RA, 346,458 inbound tourists visited Armenia in the first quarter of 2018 (an increase of $16.1 \%$ compared with the same period last year) (Social-economic situation of the RA in January-March 2018).

According to the Travel \& Tourism Competitiveness Report 2017 which is published by the World Economic Forum within the framework of the Global Competitiveness and Risks team and the Industry Partnership Programme for Aviation \& Travel, Armenia was in the 84th place among 136 countries (see Appendix 1, Table 1) (Travel \& Tourism Competitiveness Report 2017).

Armenia was ranked number one in the world in terms of population's access to clean drinking water and mobile network coverage and was at the bottom of the list in terms of the number of HIV-infected people. Armenia was also the 34th in terms of safety and security, 48th in terms of health care and hygiene, 74th in terms of tourism services infrastructure, 80th in terms of price competitiveness, 95th in terms of effectiveness of marketing and branding to attract tourists, 84th in terms of business environment, 45th in terms of human resources and labor market, 123rd in terms of ease of finding skilled employees, 107th in terms of extent of staff training, 95th in terms of international openness, 54th in terms of visa requirements, 102nd in terms of environmental sustainability, 89th in terms of natural resources, 99th in terms of cultural resources, 88th in terms of air transport, ground and port infrastructure, 80th in terms of quality of roads, 70th in terms of country brand strategy rating, 52nd in terms of government prioritization of travel and tourism industry, 65th in terms of hotel rooms, etc.

There are many types of tourism which have great potential and prospects to be developed in Armenia based on the existing resources

1. Historical-cultural tourism. Armenia's old history and culture attracts tourists. Mount Ararat is the resting place of Noah's Ark after the "great deluge". Armenia is very rich in historical, cultural monuments (about 24000), churches. The Cathedral and Churches of Echmiatsin and the Archaeological Site of Zvartnots, Monasteries of Haghpat and Sanahin, Monastery of Geghard and the Upper Azat Valley are included in the World Heritage List of UNESCO. The archaeological site of the city of Dvin, the basilica and archaeological site of Yererouk, the monastery of Noravank and the upper Amaghou Valley, the monasteries of Tatev and Tatevi Anapat and the adjacent areas of the Vorotan Valley are submitted on the Tentative List (UNESCO, Armenia). 
2. Religious tourism. Armenia was the first nation to adopt Christianity as a state religion (301 AD). Armenia may become a religious tourism centre for Christian pilgrims in the world.

3. Wellness tourism. Armenia has a great potential for the promotion of spa-resort tourism. There are 10 resorts in Armenia (Arzni, Tsakhkadzor, Jermuk, Hanqavan, Bjni, Dilijan, Sevan, Stepanavan, Syuniq, Lori) all of which have natural curable resort resources: mineral water, curable mud, turf, good conditions for climate therapy.

4. Sport and adventure tourism. Armenian mountains may attract tourists for hiking tours. Tsakhkadzor is the best place for snowboarders and ski riders in winter. For water sport, sun and beach lovers Lake Sevan is the best place. Tourists may visit the caves and waterfalls of Lastiver.

5. Eco- and agro-tourism. In Armenia there are many majestic mountains and plains, meadows, parks, plant and animal life. There are many agricultural festivals and farmer's fairs which attracks tourists to Armenian villages.

6. Wine and gastronomy tourism. Our national dishes are barbeque and kebab, dolma, harisa, khash, qufta, ghaurma, khashlama, fish ishkhan khorovats, lavash, etc. Besides Armenia is considered to be the country of wine (with more than 6000 years of history) and brandy. The wine festivals in Armenia attract many internatinal tourists every year.

7. Urban tourism. Yerevan, the capital of Armenia is 2800 years old city. It is the mix of new and old buildings and culture. Besides Yerevan, other cities worth visiting are Gyumri, Ejmiacin, Dilijan, Ijevan, Goris, etc.

8. Educational tourism. Many universities in Armenia have international programs which attract students from abroad. Besides there is UWC college in Dilijan, which is very famous in the world.

9. Scientific tourism. Armenia is well known with its scientists abroad. We have many scientific organizations, museums, archeological sites, medieval universities, reservations, observatory, which may attract international tourists.

10. Medical tourism. Armenian hospitals have all the modern medical equipment. Many tourists come here for surgery, also for dental problems.

Thus, these are the main types that now we offer to the international tourists.

Now we should discuss the opportunities of developing revolutionary tourism in Armenia.

The revolution process started on March 31, 2018, from Gyumri. The slogan of marches was 'Do a step'. The route passed through six Armenian major cities: Vanadzor, Hrazdan, Abovyan, Spitak, Dilijan, Sevan. On April 13 they came to Yerevan, the capital of Armenia. The protests in the capital lasted till April 23, when the prime minister resigned. On May 8 the revolutionary leader was elected as a prime minister by the parliament.

The political events of April-May 2018 and the peaceful and non-violent revolution were the focal point of foreign media and television companies for many days. Everyone was surprised and admired by the example of Armenia as the unique country in the world, where a revolution took place peacefully.

And what impact it has and will have on tourism trips. Naturally, many tourists who had already planned their visit to Armenia had fear with the visit. According to different tourism organizations, some tours were canceled, some visits were postponed, and there were tourists who did not cancel the visit. Moreover, it should be noted that the tourists were very enthusiastic about protests of Armenians, marches, street closures, and even participated in them (for example, a group of Chinese tourists blocked Tumanyan street together with Armenian protesters) (Chinese tourists closed the streets and joined the Armenian protestors).

The tourists were putting videos and pictures on the pages of their social websites how the Armenian demonstrators sing, dance, cook barbeque in the streets, presenting it as a unique Armenian style of revolution. The main reason of fear for the visit to Armenia was the potential danger, but tourists visiting here were convinced that they could safely walk through the city streets, enjoy the services offered by hotels, restaurants, etc.

Taking into account the above mentioned, we may say that in the second quarter of 2018, the increase in the number of tourists may not be great due to the short-term revolutionary effect. But in the long run, that impact 
may change and record positive trends, taking into account peaceful outcomes and their international media coverage.

Moreover, it should be noted that what has happened can also have a positive effect on Armenia's reputation, as following the example of Armenia, there were also protests in France, Russia, demanding the resignation of the presidents. Meanwhile, the Russian protesters chanted the slogan "Armenians could do, we can do it too", many of them hold the Armenian flag as a symbol of peaceful change and guided by the Armenian spirit (Plyushchev A.).

Now we will try to evaluate the possible effects of revolution on tourism:

Hypothesis 1: The revolution will have negative impact on the image of the country abroad and therefore the number of tourists will decrease,

Hypothesis 2: The revolution will have positive impact on the image of the country abroad and therefore the number of tourists will increase.

The accomplishment of the results of the hypotheses depends on presenting in details what has happened to international media. Of course the international media was talking about our peaceful velvet revolution. We may make a tour program of revolutionary tourism making the main routes and presenting it abroad. Here everything depends on marketing. Our promoting videos should show that we are safe and secure country, where the revolutions are being done by singing and dancing in the streets. Even special videos should be made about revolution characteristics in Armenia, which should be presented in target markets of tourism. So, taking into account our case, it is more possible the accomplishment of hypothesis 2 .

We have elaborated a model which shows the possible impacts of revolution on tourism (Appendix 2, Figure 1).

\section{Conclusion}

All this should be used for the benefit of Armenia's tourism development by presenting Armenia as a safe and secure country, and it may also be interesting for Chinese and Russian tourists (who are particularly interested in red tourism) to visit Armenia as a peaceful revolutionary country.

The main routes may include the cities Gyumri, Vanadzor, Hrazdan, Abovyan, Spitak, Dilijan, Sevan and Yerevan, where the initial revolutionary marches had started.

Besides now many suvenirs connected with the revolution are made which will also attract tourists. These are caps, t-shirts with the pictures of revolutionary leader, and with the word "with courage", which was the main slogan during the marches.

Armenian revolution is named velvet revolution, so this tourism may be described as "velvet tourism".

Thus the main steps should be good marketing and promotion of Armenian tourism product abroad, presenting Armenia as a safe country, with old history and culture, hospitality and tasty cuisine, old civilization and first religious country, and having a nation with high spirit which could do a velvet revolution.

\section{References}

1. Chinese tourists closed the streets and joined the Armenian protestors [Electronic resource]. Available at: https://factor.am/51223.html (Accessed: 10.05.18) (in Armenian).

2. Haines, G. 10 surprising destinations where tourism is booming in 2017 [Electronic resource]. Available at: https://www.telegraph.co.uk/travel/news/surprising-countries-where-tourism-is-booming-in-2017/ (Accessed: 11.06.18).

3. Hunse, L. Red tourism in China. Available at: http://journeying.ru/krasniy-turizm-v-kitae.html (Accessed: 10.05.18) (in Russian).

4. International Tourism Results 2017: the highest in seven years. Available at: http://media.unwto.org/pressrelease/2018-01-15/2017-international-tourism-results-highest-seven-years (Accessed: 10.05.18).

5. Order of the Federal Agency for Tourism (Rosturizm) of May 15, 2006 No. 74 Moscow On the procedure for determining tourist organizations that have the right to carry out activities within the framework of the implementation of the Agreement between the Government of the Russian Federation and the Government of the People's Republic of China on visa-free group travels of 29 February 2000 [Electronic resource]. Available at: https://rg.ru/2006/06/07/turizm-dok.html (Accessed: 10.05.18) (in Russian). 
6. Plyushchev, A. Comments: Russia impressed by Armenia [Electronic resource]. Available at: https://www.dw.com/ru/\%D0\%BA\%D0\%BE\%D0\%BC\%D0\%BC\%D0\%B5\%D0\%BD\%D1\%82\%D0\% B0\%D1\%80\%D0\%B8\%D0\%B9-\%D1\%80\%D0\%BE\%D1\%81\%D1\%81\%D0\%B8\%D1\%8F-

$\% \mathrm{D} 0 \% \mathrm{BF} \% \mathrm{D} 0 \% \mathrm{BE} \% \mathrm{D} 0 \% \mathrm{~B} 4-$

\%D0\%B2\%D0\%BF\%D0\%B5\%D1\%87\%D0\%B0\%D1\%82\%D0\%BB\%D0\%B5\%D0\%BD\%D0\%B8\%

D0\%B5\%D0\%BC-\%D0\%BE\%D1\%82-

\%D0\%B0\%D1\%80\%D0\%BC\%D0\%B5\%D0\%BD\%D0\%B8\%D0\%B8/a-43673812,

(Accessed:

10.05.18) (in Russian).

7. Red tourism. Why chinese tourists are attracted by the revolutionary history of Russia? [Electronic resource]. Available at: https://www.youtube.com/watch?v=HTK0WMp7R3Y\&feature=youtu.be (Accessed: 10.05.18) (in Russian).

8. Shanchzhun, Z. (2009). The development of red tourism [Electronic resource]. Available at: http://redrouterussia.com/en/pages/razvitie_red_tour.php. (Accessed: 10.05.18).

9. Social-Economic Situation of the RA (2017). National Statistical Service of the RA [Electronic resource]. Available at: www.armstat.am (in Armenian). (Accessed: 10.05.18).

10. Social-economic situation of the RA in January-March (2018). [Electronic resource]. Available at: http://armstat.am/file/article/sv_03_18a_421.pdf (Accessed: 10.05.18) (in Armenian).

11. The number of tourists from China to Russia reached up to $1.5 \mathrm{mn}$ in 2017.[Electronic resource]. Available at: https://regnum.ru/news/2387546.html (Accessed: 10.05.18) (in Russian).

12. Travel \& Tourism Competitiveness Report (2017). World Economic Forum, Geneva, 2017.

13.Travel \& Tourism Economic Impact Armenia (2018). p. 1, World Travel and Tourism Council [Electronic resource]. Available at: http://www.wttc.org (Accessed: 10.05.18).

14.UNESCO, Armenia: Properties inscribed on the World Heritage List. [Electronic resource]. Available at: http://whc.unesco.org/en/statesparties/am (Accessed: 10.05.18).

15. Vodopyanova A. Red tourism - a type of pilgrimage for Chinese citizens [Electronic resource]. Available at: http://rusturinvest.ru/article/krasnyy-turizm-eto-svoego-roda-palomnichestvo-dl-1400.html (Accessed: 10.05.18) (in Russian).

16. Wong E. Revolution Isn't a Party, but It Draws Tourists [Electronic resource]. Available at: https://www.nytimes.com/2010/12/31/world/asia/31china.html?_r=1 (Accessed: 10.05.18).

\section{Appendix 1}

Table 1. Travel \& Tourism Competitiveness Index of Armenia, 2017

\begin{tabular}{|l|c|c|}
\hline \multirow{2}{*}{} & \multicolumn{2}{|c|}{2017} \\
\cline { 2 - 3 } & Rank in 136 countries & Score (1-7) \\
\hline Travel \& Tourism Competitiveness Index & 84 & 4.53 \\
\hline Business environment & 39 & 5.9 \\
\hline Safety and security & 34 & 5.9 \\
\hline Health and hygiene & 48 & 4.8 \\
\hline Human resources and labor market & 45 & 4.3 \\
\hline ICT readiness & 71 & 4.6 \\
\hline Prioritization of T ravel \& Tourism & 71 & 2.6 \\
\hline International Openness & 95 & 4.8 \\
\hline Price competitiveness & 80 & 3.8 \\
\hline Environmental sustainability & 102 & 2.2 \\
\hline Air transport infrastructure & 88 & 2.9 \\
\hline Ground and port infrastructure & 88 & 3.9 \\
\hline Tourist service infrastructure & 74 & 2.6 \\
\hline Natural resources & 89 & 1.4 \\
\hline Cultural resources and business travel & 99 & \\
\hline
\end{tabular}




\section{Appendix 2}

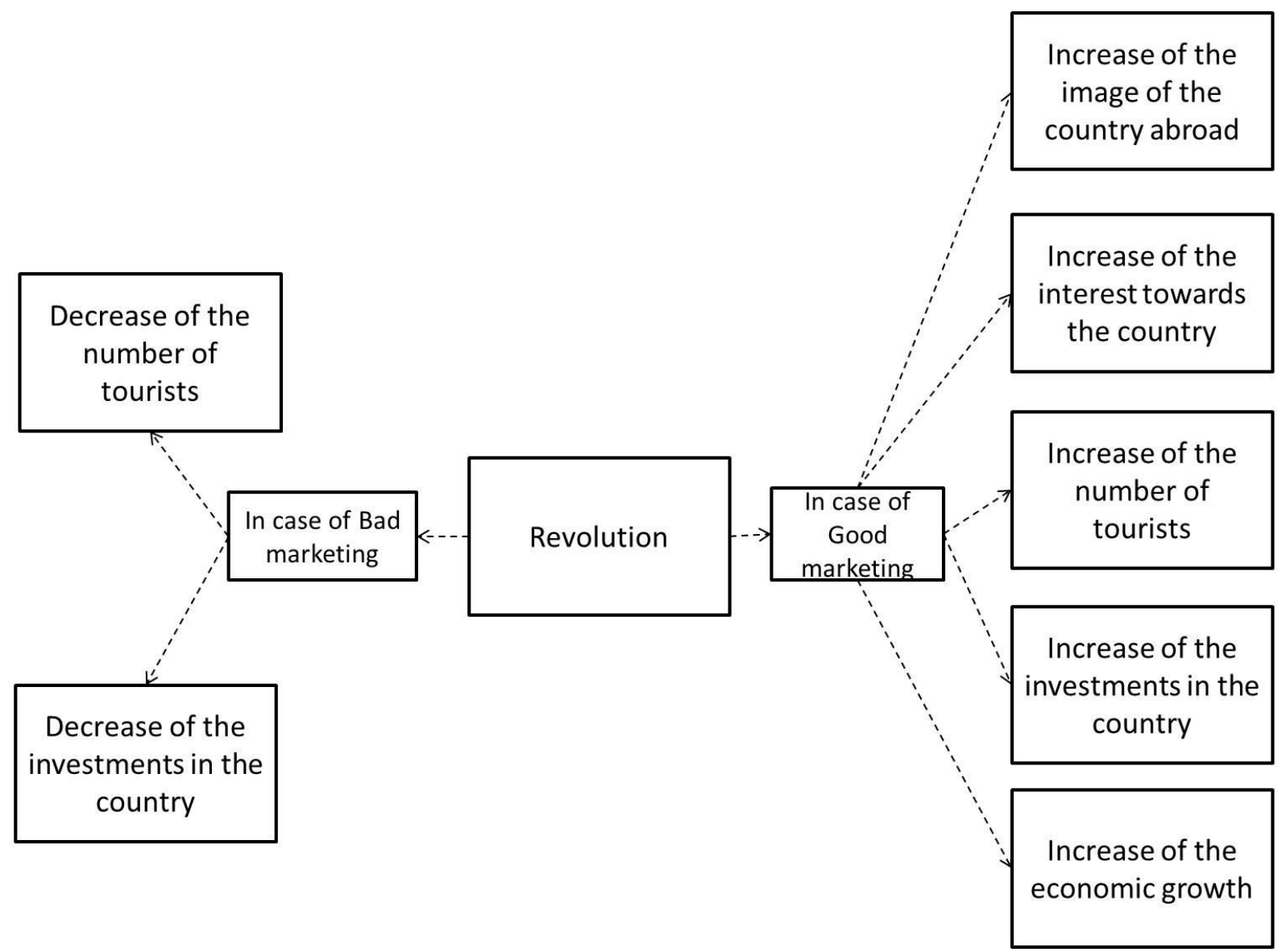

Figure 1. Revolution impact model in Armenia

Source: elaborated and offered by the author. 